\title{
THE Drosophila COMMUNITY IN XEROPHYTIC VEGETATIONS OF THE UPPER PARANA-PARAGUAY RIVER BASIN
}

\author{
MATEUS, R. P. ${ }^{1}$, BUSCHINI, M. L. T. ${ }^{1}$ and SENE, F. M. ${ }^{2}$ \\ ${ }^{1}$ Departamento de Ciências Biológicas, Universidade Estadual do Centro-Oeste do Paraná - UNICENTRO/CEDETEG, \\ Rua Simeão Camargo Varela de Sá, 3, CEP 85040-080, Guarapuava, PR, Brasil \\ ${ }^{2}$ Departamento de Genética, Faculdade de Medicina de Ribeirão Preto - FMRP/USP, \\ Avenida Bandeirantes, 3900, CEP 14049-900, Ribeirão Preto, SP, Brasil \\ Correspondence to: Rogério Pincela Mateus, Departamento de Ciências Biológicas, Universidade Estadual do \\ Centro-Oeste do Paraná - UNICENTRO/CEDETEG, Rua Simeão Camargo Varela de Sá, 3, CEP 85040-080, \\ Guarapuava, PR, Brasil, e-mail: rmateus@unicentro.br \\ Received August 18, 2004 - Accepted December 8, 2004 - Distributed May 31, 2006
}

(With 2 figures)

\begin{abstract}
The genus Drosophila is the most abundant in the Drosophilidae family. Some species are endemic to certain regions and others are cosmopolitans. In Brazil, there are several ecosystems to explore regarding the composition and ecological aspects of Drosophila. Xerophytic areas are an example. They can be found in the South and Southeast of Brazil as islands, a result of paleoclimatic cycle changes. The aim of the present work is to provide information about the composition of the Drosophila community in eight xerophytic areas (where the cactus Cereus hildmaniannus occurs) in the South and Southeast of Brazil. This work is an important step in the study of quantitative ecological aspects of the Drosophila community in xerophytic areas that form continental islands in the Neotropical region. The composition of the Drosophila community which was found is compatible with previous work in several aspects. The ecological indexes showed a possible positive association between diversity and the degree of preservation of the studied areas. São Paulo state communities presented the highest similarity among the sites tested, although no statistical significant correlation between the Jaccard index and geographical distance was found using the Mantel test.
\end{abstract}

Keywords: Drosophila community, Drosophilidae family, diversity, xerophytic vegetation.

\section{RESUMO}

\section{Comunidade de Drosophila em vegetações xerofíticas do alto da bacia dos rios Paraná-Paraguai}

O gênero Drosophila é o mais abundante da família Drosophilidae. Algumas espécies são endêmicas em certas regiões e outras são cosmopolitas. No Brasil existem diversos ecossistemas a serem explorados a respeito da composição e aspectos ecológicos de Drosophila. Áreas xerofíticas são um exemplo, podendo ser consideradas como ilhas continentais no sul e sudeste do Brasil, resultado de mudanças paleoclimáticas cíclicas. O presente trabalho teve o objetivo de fornecer informação sobre a composição da comunidade de Drosophila em oito áreas xerofíticas (onde o cacto Cereus hildmaniannus ocorre) no sul e sudeste do Brasil. Este trabalho é um passo importante no estudo de aspectos ecológicos quantitativos das comunidades de Drosophila em ilhas de vegetação xerofítica na região Neotropical. De modo geral, a composição das comunidades de Drosophila está de acordo com trabalhos anteriores em diversos aspectos. Os índices ecológicos mostraram uma possível associação positiva da diversidade e o grau de preservação das áreas. As comunidades do estado de São Paulo apresentaram as maiores similaridades entre elas, apesar de não ter sido encontrada correlação estatisticamente significativa entre o índice de Jaccard e distâncias geográficas entre as comunidades, através do teste de Mantel.

Palavras-chave: comunidade de Drosophila, família Drosophilidae, diversidade, vegetação xerofítica. 


\section{INTRODUCTION}

Although in the $18^{\text {th }}$ century Scopoli, Linné and Fabricius were the first to describe the species which are today allocated to the family Drosophilidae, Duda (1924a, 1924b, 1925) could be considered the pioneer in the systematics of this group. Moreover, Sturtevant, well known for his classic work $(1921,1939,1942)$, is one of the most important researchers within this family. The first data on the Brazilian Drosophila community were published by Duda (1925). In the southeast region of Brazil, Dobzhansky \& Pavan (1943) were pioneers and described several new species. After 1940, much work about Brazilian Drosophila fauna was published (Pavan \& Cunha, 1947; Dobzhansky \& Pavan, 1950; Pavan, 1950; 1959) including the first Brazilian Drosophila species list (Mourão et al., 1965). Later, other authors analyzed the Drosophila fauna in the morphoclimatic domains of Brazil in an effort to understand the geographical distribution of the most common species better (Sene et al., 1980; Vilela et al., 1983; Val et al., 1981).

The Drosophilidae family is composed by 65 genus and more than 3,500 described species that occur in a number of ecosystems all over the world (Bächli, 1998). Most genera are found in tropical regions. The Drosophila genus is the most abundant and comprises around 53\% of the total species. Some of them are endemic to certain regions and others are cosmopolitan, dispersed mostly in association with human activity. Grimaldi (1990) reviewed the classification of the Drosophilidae family based on a cladistic analysis using maximum parsimony. This author studied 217 morphological characters of adults and 120 species representative of the family and concluded that they constitute a monophyletic group. The Drosophila genus probably originated in the tropics (Stalker, 1976) and different members of it expanded their distribution to the temperate zones, where the ability to use resources under extreme environmental conditions was selected. This process might have been repeated several times during the evolution of the genus.

Today, most research using Drosophila species is being conducted in the fields of Molecular Biology and Genetics, but it was only in the early twentieth century that Drosophila melanogaster was recognized as useful for genetic analyses (Castle, 1906). Despite the large number of studies using Drosophila as a model organism in these fields, Brazilian species still require further studies regarding many aspects of ecology, systematics, genetics and evolution.

Some ecological studies with Drosophila have been carried out, especially regarding fly activity during the day (Klaczko et al., 1983; Medeiros, 2000), the appropriate period of the day for sampling (Pavan et al., 1950; Belo \& Oliveira-Filho, 1978), and the spatial distribution of species (horizontal: Dobzhanzky \& Pavan, 1950; Burla et al., 1950; Pavan, 1959; Medeiros, 2000; and vertical: Sene et al., 1981; Kratz et al., 1982 e Tidon-Sklorz \& Sene, 1992). However, comparison among areas has received little attention (Medeiros \& Klaczko, 2004, for example) and still remains an open area of study for Brazilian Drosophila species.

Taking this into account, there are several ecosystems to explore in Brazil regarding composition and ecological aspects of Drosophila. Xerophytic areas, determined by the presence of drytype vegetation with the occurrence of different types of cacti, are such an example. Currently, as well as the center areas of cacti occurrence, such as the Brazilian Caatinga and Argentinean Chaco, these plants can be found in the South, Southeast, and Central regions of Brazil on islands, a result of the cycled paleoclimatic changes. These cycles alternated between cold/dry and warm/humid. In the first case, xerophytic areas expanded from the center areas over the continent and in the second, they retracted forming refuges (islands) between them (Bigarella et al., 1975; Ab'Saber, 1977; Vanzolini, 1981). Therefore, refuges are important for biodiversity, ecological and evolutionary studies of several groups, including Drosophila species that breed specifically in rotting cactus tissue, as do flies of the D. repleta group.

The aim of the present work is to provide information about the composition of the Drosophila community in eight xerophytic areas (where cactus Cereus hildmaniannus occurs) in the south and southeast regions of Brazil. This will provide valuable information for further studies regarding ecology, genetics and the evolution of geographically isolated Drosophila populations.

\section{MATERIAL AND METHODS}

The places and date of collections are summarized in Table 1. The samples were collected in 
TABLE 1

Locations, codes, coordinates and number of traps used in the Drosophila collections made in eight xerophytic areas in South and Southeast Brazil.

\begin{tabular}{|l|l|c|c|}
\hline \multicolumn{1}{|c|}{ Localities } & Code & Coordinates & Number of traps \\
\hline Serrana - SP & SER & $21^{\circ} 15^{\prime} \mathrm{S}, 47^{\circ} 34^{\prime} \mathrm{W}$ & 30 \\
\hline Itatiba - SP & ITA & $22^{\circ} 56^{\prime} \mathrm{S}, 46^{\circ} 55^{\prime} \mathrm{W}$ & 20 \\
\hline Santa Maria da Serra - SP & SMS & $22^{\circ} 34^{\prime} \mathrm{S}, 48^{\circ} 12^{\prime} \mathrm{W}$ & 20 \\
\hline Itirapina - SP & ITI & $22^{\circ} 16^{\prime} \mathrm{S}, 47^{\circ} 48^{\prime} \mathrm{W}$ & 20 \\
\hline Salto Santa Rosa/Tibagi - PR & SSR & $24^{\circ} 37^{\prime} \mathrm{S}, 50^{\circ} 33^{\prime} \mathrm{W}$ & 20 \\
\hline Canyon Guartelá/Tibagi - PR & GUA & $24^{\circ} 32^{\prime} \mathrm{S}, 50^{\circ} 18^{\prime} \mathrm{W}$ & 20 \\
\hline Sengés - PR & SEN & $24^{\circ} 07^{\prime} \mathrm{S}, 49^{\circ} 23^{\prime} \mathrm{W}$ & 20 \\
\hline Cianorte - PR & CIA & $23^{\circ} 34^{\prime} \mathrm{S}, 52^{\circ} 33^{\prime} \mathrm{W}$ & \\
\hline
\end{tabular}

woodlands composed of xerophytic vegetation in mesophytic forests in the valleys of the upper portion of the Parana-Paraguay river basin. These areas are at different stages of perturbation, ranging from use for livestock raising next to a road (Itatiba - SP and Sengés - PR) to a State Park preservation area (Canyon Guartelá - PR). All collections were made at the end of the wet period, which corresponds to February to May in two different years (1999 and 2000).

\section{Collections}

For three days, the adult flies were attracted to fermented banana and orange in open traps, dispersed no closer than $15 \mathrm{~m}$ from each other, hung on branches at $\pm 1.5 \mathrm{~m}$ height from the ground. After this period, the flies were captured with entomological nets, put in glass jars with culture medium and taken to the laboratory alive, where they were identified.

It is difficult to identify members of the Drosophila repleta and D. willistoni groups to a certain degree. The females of the first group are shown as unidentified if the diagnostic characteristic is the male aedeagus. In terms of the Drosophila willistoni group, identification using genetic traits is more reliable but was not done. Therefore, the cryptic species were grouped as "repleta group" and "D. willistoni group", respectively. The unidentified "repleta group like" species were not considered in the analyses.

\section{Data analyses}

In order to verify the species occurrence qualitatively, the Occurrence Constancy Method
(Dajoz, 1983) was used. The constancy value (c) was obtained by dividing the number of collections in which one species occurred by the total number of collections, and then multiplying that result by 100. Species with index $c \geq 50$ were considered constants. Accessory species were those with $25 \leq c<50$. Accidental species had $c<25$. Species that occurred in only one area were considered exclusive.

Drosophila communities were analyzed using several ecological indexes: Berger-Parker (1/d), Shannon-Wienner (H'), Simpson (D), Margalef $\left(\mathrm{D}_{\mathrm{Mg}}\right)$, Menhinick $\left(\mathrm{D}_{\mathrm{Mn}}\right)$ and Jaccard $(\mathrm{J})$. A nonparametric ANOVA, Kruskal-Wallis, was used to determine if there were differences in the median abundance between communities. Afterwards, a multiple comparison among samples (similar to the Tukey test) was made to determine whether significant differences occurred between the samples (Zar, 1999).

In order to verify the relationships among communities, two cluster analyses were performed: 1) using presence and absence of species; and 2) using the number of specimens collected for each species in each area. The phenograms were built in Minitab® for Windows Release 10.1 software selecting Euclidean distance and Single Linkage methods in both approaches.

To analyze if there is an association of community similarities and geographical distances, a Mantel test was done using the TFPGA software (Miller, 1997) comparing two matrixes: Jaccard indexes and geographical distances between a pair wise of communities. 


\section{RESULTS AND DISCUSSION}

In this study we were able to identify a total of 10,464 flies belonging to 4 subgenera, 10 groups and at least 30 different species of Drosophila (Table 2). Constant species $(c \geq 50)$ represented approximately $63 \%$ of the total collected species (19 out of 30). Seven species were considered accessory $(\sim 23 \%)$ and 4 accidental species were found $(\sim 13 \%)$. All subgenera showed constant species, except for the Dorsilopha subgenus that showed only one accidental species (Drosophila busckii).

Five species (Drosophila polymorpha, D. antonietae, D. mercatorum, D. simulans and D. sturtevanti) were considered abundant, and were collected in all 8 areas (Serrana - SP, Itatiba - SP, Santa Maria da Serra - SP, Itirapina - SP, Salto Santa Rosa - PR, Canyon Guartelá - PR, Sengés - PR and Cianorte - PR). This result is compatible with previous Drosophila surveys.

Drosophila polymorpha was collected from Guatemala to Brazil and in different types of environments: forests, cerrado, restinga, and also associated with human presence. It is a relatively abundant species in different morphoclimatic domains, except in the caatinga (Sene et al., 1980).

Drosophila antonietae was expected to be collected in all areas, as it is a cactophilic species that occurs in the south and southeast regions of Brazil, and north of the eastern boundary of the Argentinean Chaco. This species always occurs associated with the columnar cactus Cereus hildmaniannus in the xerophytic vegetation of gallery and mesophytic forests in the valleys of the Paraná-Uruguai river basin (Tidon-Sklorz \& Sene, 2001). This pattern of distribution that isolates Drosophila antonietae from other $D$. buzzatii cluster species coincides with defined patterns of other dipterans and also with regions of endemism, suggesting vicariant events such as zoogeographic barriers established in earlier geological eras or climatic events that prevented gene flow enabling the accumulation of differences between populations (Amorin \& Pires, 1996). This pattern of distribution is also observed regarding plant distribution restricted to the xerophytic caatinga and chaco regions (Duvernell \& Eanes, 2000).

Drosophila mercatorum is quite common in natural environments in South America, especially in open areas (Sene et al., 1981; Vilela et al., 1983).
Drosophila simulans is an introduced species that has been collected in high frequency in several places (Dobzhansky \& Pavan, 1950; Pavan, 1959; Sene et al., 1980; Tidon-Sklorz \& Sene, 1992), also in open areas (Perondini et al., 1979).

Drosophila sturtevanti is a widely distributed species in Central and South America occurring in different morphoclimatic domains (Tidon-Sklorz \& Sene, 1999).

Exclusive species appeared in Salto Santa Rosa - PR (Drosophila busckii) and Canyon Guartelá - PR (Drosophila guaraja, D. carolinae and D. nigricruria). Drosophila busckii was not expected to be collected in Salto Santa Rosa - PR as it is an introduced species in Brazil and is frequently associated with environments modified by man (Tidon-Sklorz \& Sene, 1999). However, it has been collected in natural environments mainly in dry open vegetations (Bizzo \& Sene, 1982; Tidon-Sklorz \& Sene, 1992). Among the exclusive species collected in Canyon Guartelá - PR, Drosophila guaraja was registered in Brazil only in Boracéia - SP (Val \& Kaneshiro, 1988). This is, therefore, the first record of it outside this locality in Brazil. Drosophila carolinae has been collected only in rain forests in Brazil (Vilela, 1983) and for this reason was not expected to be found in areas of xerophytic vegetation. However, Canyon Guartelá - PR is one of the most preserved areas surveyed and the cacti are distributed under a woodland region inside the State Park, a fact that could explain its presence. Drosophila nigricruria is the only exclusive species that has wide geographical distribution. Nevertheless, it was collected only in this area in this study. Medeiros \& Klaczko (2004) also collected this species in Barreiro Rico farm (between $48^{\circ} 05^{\prime}$ $11^{\prime \prime} \mathrm{W}-22^{\circ} 41^{\prime} 15^{\prime \prime} \mathrm{S}$ and $48^{\circ} 04^{\prime} 52^{\prime \prime} \mathrm{W}-22^{\circ}$ 41 ' 26" S), an interior plateau which has a semi deciduous forest and one of the three remaining forests in São Paulo State where collections were made by these authors.

The Drosophila subgenus showed the highest richness ( 7 groups and 22 species), with 7 species belonging to the Drosophila repleta group. The second highest richness was found in the Sophophora subgenus (3 groups and 6 species). This richness distribution among subgenera has been observed in other studies (Sene et al., 1981; Tidon-Sklorz \& Sene, 1995; Tidon-Sklorz \& Sene, 1999; Medeiros \& Klaczko, 2004). 


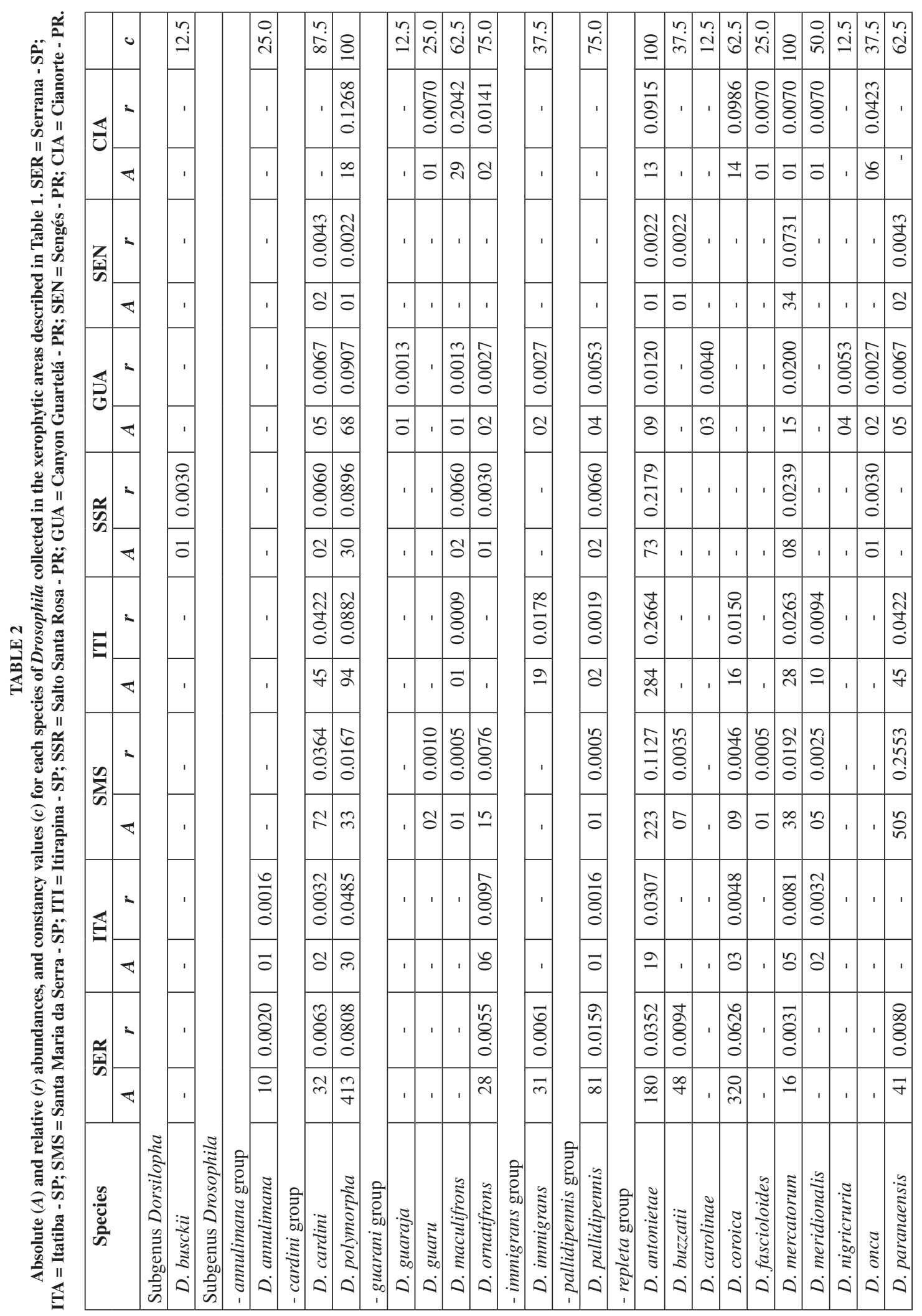




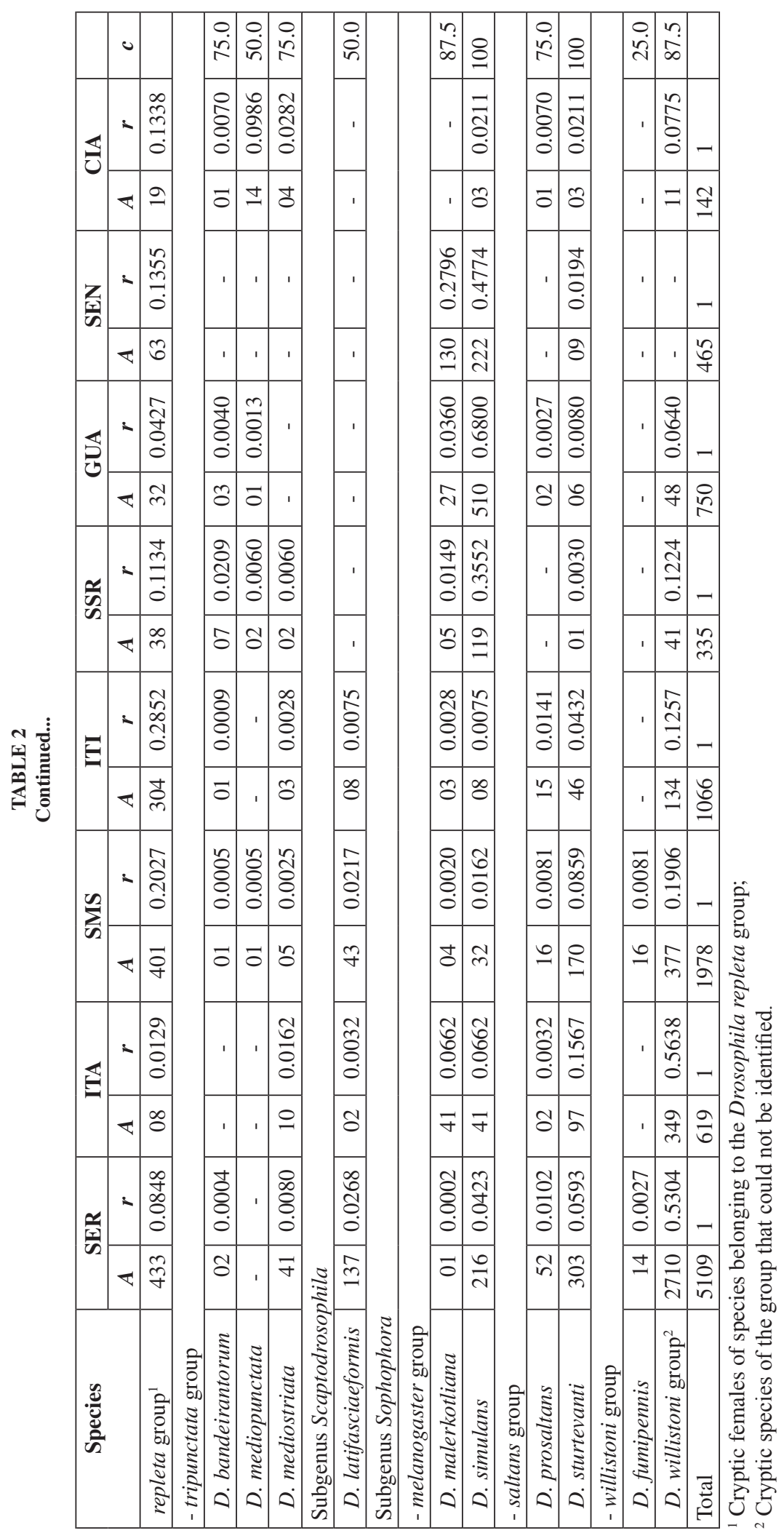


The introduced drosophilid species, Zaprionus indianus (Vilela, 1999), was found in all collections (1,459 specimens in Serrana; 317 in Itatiba; 409 in Santa Maria da Serra; 302 in Itirapina; 42 in Salto Santa Rosa; 117 in Guartelá; 598 in Sengés; and 8 in Cianorte). The events associated to biological invasions are divided into three categories: arrival, establishment, and integration (Vermeij, 1996). According to Moraes et al. (2000), Zaprionus indianus has gone through all three and is probably competing unfavorably with other similar species in the Southeast of Brazil, as a fall in relative frequency has been observed. The introduction of an exotic Drosophila species in Brazil is not an uncommon event. In 1976, Val \& Sene (1980) collected a large number of Drosophila malerkotliana in northeastern Brazil, a species which was not recorded in extensive earlier collections. Currently in our surveys, Drosophila malerkotliana is collected almost throughout Brazil, though always at a low relative frequency.

Twenty-three different species were collected in Santa Maria da Serra - SP, 20 species in Serrana - SP and in Canyon Guartelá - PR, 18 in Itirapina - SP, 17 in Cianorte - PR, 16 in Itatiba - SP and Salto Santa Rosa - PR and 9 in Sengés - PR (Table 3). Medeiros \& Klaczko (2004) described the last inventory of Drosophila fauna in Brazil, surveyed in three forests remaining in São Paulo State. These authors obtained 57, 76 and 90 different species in three studied areas. These numbers of species are greater than those observed here, perhaps a result of differences in the collection method or simply because the surveyed areas are distinct in their vegetation constitution (forest and xerophytic vegetation). The highest total abundance was detected in Serrana - SP (4676 specimens) and the lowest in Cianorte - PR (123 specimens) (Table 3).

According to ecological indexes (Table 3), Cianorte - PR presented higher values in almost all indexes $\left(1 / \mathrm{d}=4.2409 ; \mathrm{H}^{\prime}=2.3116 ; \mathrm{D}_{\mathrm{Mg}}=3.3249\right.$; $\mathrm{D}_{\mathrm{Mn}}=1.5328$ ), except for Simpson (D) which showed Canyon Guartelá - PR to be the most diverse area $(D=0.5196)$. Canyon Guartelá - PR also showed one of the highest indexes in two more cases $\left(\mathrm{D}_{\mathrm{Mg}}=2.8891 ; \mathrm{D}_{\mathrm{Mn}}=0.7464\right)$. Sengés $\mathrm{PR}$, Itatiba-SP and Serrana - SP showed the lowest values for most indexes. Santa Maria da Serra - SP, Itirapina - SP and Salto Santa Rosa PR showed intermediate values for most indexes. These observations are compatible with the superficial evaluation of degradation in these areas. Cianorte - PR is located next to a road, but on a high slope board of the Ligeiro river, with difficult access for human degradation. Canyon Guartelá - PR is a woodland area inside the Canyon Guartelá State Park of Paraná state, as mentioned earlier. Therefore, it is a highly preserved area. Sengés - PR is the most degraded area, next to a road, home to livestock raising and under high influence from human activity. Serrana - SP is a preserved area on the top of a hill which is difficult to access. The lower diversity indexes found for this area must be due to the higher number of traps used in this collection (Table 1). The other areas were expected

TABLE 3

Richness (S), Absolute Abundance (A), Berger-Parker index (1/d), Shannon index (H'), Simpson index (D), Margalef index $\left(\mathrm{D}_{\mathrm{Mg}}\right)$ and Menhinick index $\left(\mathrm{D}_{\mathrm{Mn}}\right)$. Highlighted boxes and bold numbers indicate highest and lowest values, respectively. SER = Serrana - SP; ITA = Itatiba - SP; SMS = Santa Maria da Serra - SP; ITI = Itirapina - SP; SSR = Salto Santa Rosa - PR; GUA = Canyon Guartelá - PR; SEN = Sengés - PR; CIA = Cianorte - PR.

\begin{tabular}{|c|c|c|c|c|c|c|c|}
\hline Collections & $\mathbf{S}$ & $\boldsymbol{A}$ & $\mathbf{1 / d}$ & $\mathbf{H}^{\prime}$ & $\mathbf{D}$ & $\mathbf{D}_{\mathbf{M g}}$ & $\mathbf{D}_{\mathbf{M n}}$ \\
\hline SER & 20 & 4676 & 1.7253 & 1.6657 & 0.3577 & 2.2485 & $\mathbf{0 . 2 9 2 5}$ \\
\hline ITA & 16 & 611 & 1.7507 & 1.5046 & 0.3633 & 2.3382 & 0.6473 \\
\hline SMS & 23 & 1577 & 3.1230 & 1.9868 & 0.1954 & 2.9878 & 0.5792 \\
\hline ITI & 18 & 762 & 2.6831 & 2.0363 & 0.1978 & 2.5618 & 0.6521 \\
\hline SSR & 16 & 297 & 2.4956 & 1.7158 & 0.2495 & 2.6345 & 0.9284 \\
\hline GUA & 20 & 718 & $\mathbf{1 . 4 0 7 9}$ & 1.2119 & 0.5196 & 2.8891 & 0.7464 \\
\hline SEN & 9 & 402 & 1.8109 & $\mathbf{1 . 0 8 4 5}$ & 0.4158 & $\mathbf{1 . 3 3 4 1}$ & 0.4489 \\
\hline CIA & 17 & 123 & 4.2409 & 2.3116 & $\mathbf{0 . 1 2 0 2}$ & 3.3249 & 1.5328 \\
\hline
\end{tabular}


to have intermediate values of diversity, as they are small conservation areas inside farms.

The pairwise comparison of communities using the Jaccard index (Table 4) showed that São Paulo state communities (Serrana - SP, Itatiba - SP, Santa Maria da Serra - SP and Itirapina - SP) had the highest similarity among all comparisons $(\mathrm{J}>0.62)$. The same pattern was not observed among Paraná state communities and also between both states, with the exception of the index obtained between Santa Maria da Serra - SP and Cianorte - PR ( $=0.667)$, and between Salto Santa Rosa - PR and Canyon Guartelá - PR $(\mathrm{J}=0.636)$. The cluster analyses using presence and absence of species data (Fig. 1), in spite of a low similarity level (33.86\%), also grouped all São Paulo State communities together. The most divergent community was Sengés - PR. Fig. 2 depicts the cluster grouping of all communities using absolute abundance $(A)$ data. Higher levels of similarity were found, but no clear association of communities was encountered. In this figure, Serrana - SP was the most different community.

The Kruskal-Wallis test, adjusted for ties, showed that the communities are significantly different when an overall comparison was made $(\mathrm{H}=24.24$; d.f. $=7 ; \mathrm{p}=0.001)$. The multiple pairwise comparisons of communities are presented in Table 5. Serrana - SP, Santa Maria da Serra - SP

TABLE 4

Jaccard $(\mathrm{J})$ indexes between pairwise of populations. Highlighted boxes: $\mathrm{J}>\mathbf{0 . 6 2}$. Bold number indicates the lowest Jacard value. SER = Serrana - SP; ITA = Itatiba - SP; SMS = Santa Maria da Serra - SP; ITI = Itirapina - SP; SSR = Salto Santa Rosa - PR; GUA = Canyon Guartelá - PR; SEN = Sengés - PR; CIA = Cianorte - PR.

\begin{tabular}{|c|c|c|c|c|c|c|c|}
\hline Collections & SER & ITA & SMS & ITI & SSR & GUA & SEN \\
\hline ITA & 0.714 & - & - & - & - & - & - \\
\hline SMS & 0.720 & 0.625 & - & - & - & - & - \\
\hline ITI & 0.727 & 0.684 & 0.708 & - & - & - & - \\
\hline SSR & 0.478 & 0.524 & 0.560 & 0.545 & - & - & - \\
\hline GUA & 0.538 & 0.440 & 0.536 & 0.583 & 0.636 & - & - \\
\hline SEN & 0.450 & 0.389 & 0.391 & 0.421 & 0.389 & 0.381 & - \\
\hline CIA & 0.423 & 0.500 & 0.667 & 0.522 & 0.571 & 0.480 & $\mathbf{0 . 2 3 8}$ \\
\hline
\end{tabular}

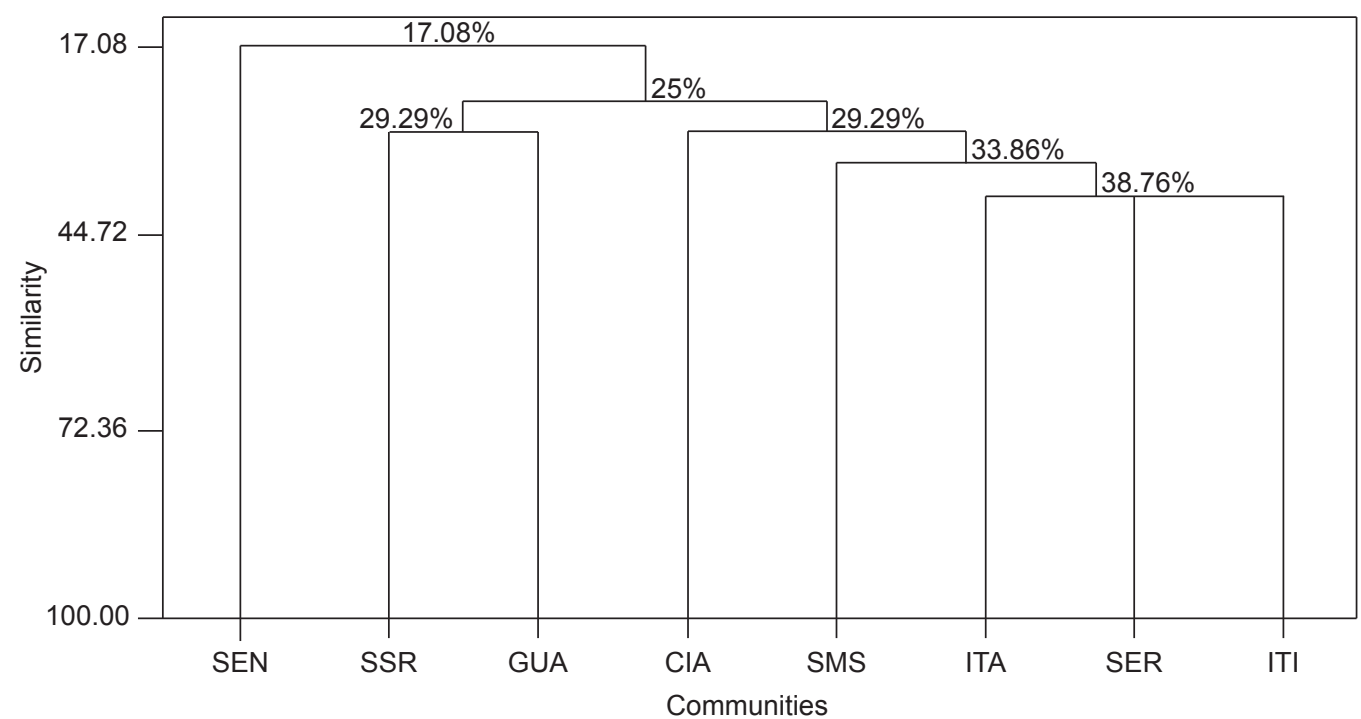

Fig. 1 - Cluster analysis using presence and absence of species in 8 xerophytic areas in Brazil obtained selecting Euclidean distance and the Single Linkage method. 


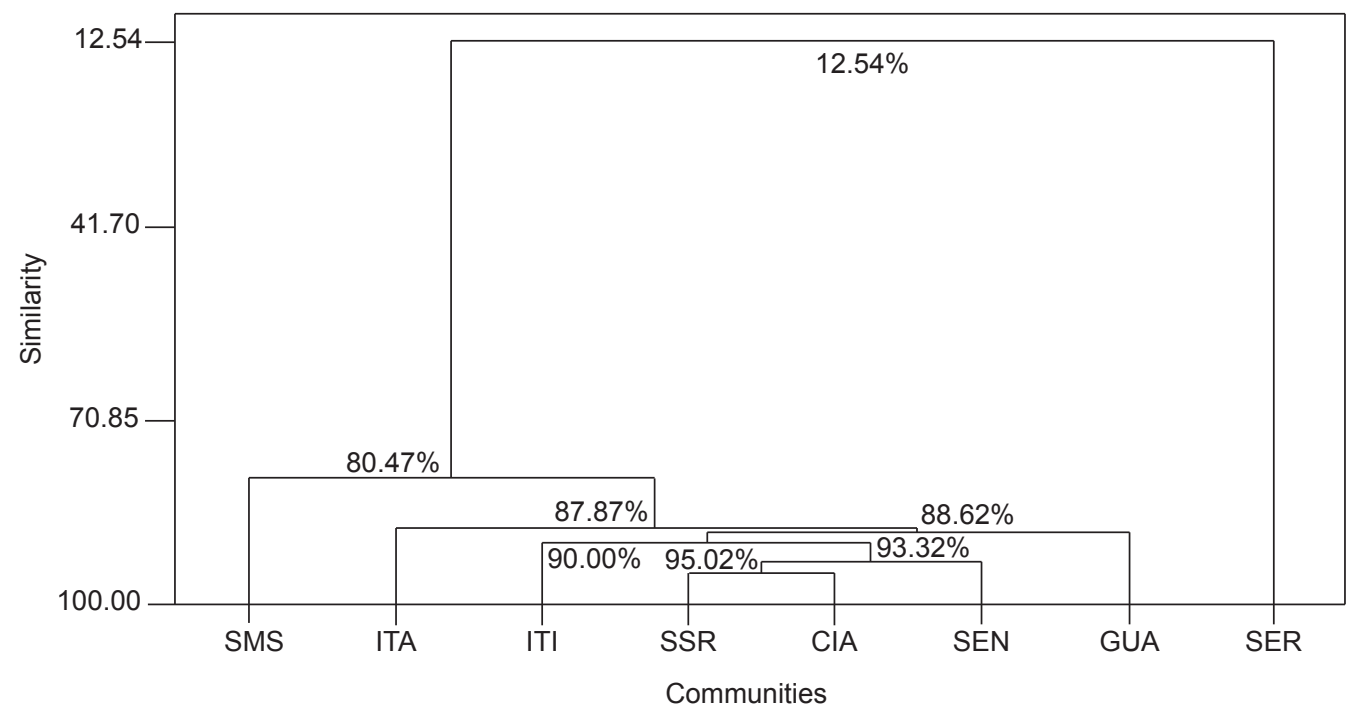

Fig. 2 - Cluster analysis using number of specimens collected for each species in 8 xerophytic areas in Brazil obtained selecting Euclidean distance and the Single Linkage method.

TABLE 5

$Q$ values obtained after multiple comparisons among samples similar to the Tukey test. Significance level $Q_{0.05,8}=3.1240$.

SER = Serrana - SP; ITA = Itatiba - SP; SMS = Santa Maria da Serra - SP; ITI = Itirapina - SP; SSR = Salto Santa Rosa - PR; GUA = Canyon Guartelá - PR; SEN = Sengés - PR; CIA = Cianorte - PR .

\begin{tabular}{|c|c|c|c|c|c|c|c|}
\hline Collections & SER & ITA & SMS & ITI & SSR & GUA & SEN \\
\hline ITA & $3.7738^{*}$ & - & - & - & - & - & - \\
\hline SMS & 0.6361 & $3.2909^{*}$ & - & - & - & - & - \\
\hline ITI & 2.3749 & 1.4378 & 1.8338 & - & - & - & - \\
\hline SSR & $4.4106^{*}$ & 0.6041 & $3.9471^{*}$ & 2.0594 & - & - & - \\
\hline GUA & 2.9335 & 1.0076 & 2.3983 & 0.4809 & 1.6445 & - & - \\
\hline SEN & $5.4964^{*}$ & 2.2571 & $5.1176^{*}$ & $3.5129 *$ & 1.7445 & $3.1851^{*}$ & - \\
\hline CIA & $4.4444^{*}$ & 0.5764 & $3.9781^{*}$ & 2.0547 & 0.0366 & 1.6328 & 1.7943 \\
\hline
\end{tabular}

* significant different pairwise comparison.

and Sengés - PR communities were the most distinct when compared individually to the others (4 significant different comparisons for each one). Itirapina - SP and Canyon Guartelá - PR were the most similar communities when compared to each community sampled (only one significant difference for each one). All these comparisons (Jaccard index, cluster analyses and multiple pairwise comparisons) showed that a higher similarity occurred among São Paulo State communities, although no positive significant correlation was found in the Mantel test comparing Jaccard index and geographical distances $(r=-0.3235 ; p=0.0839)$.
The community composition survey is an important step for several studies in a wide range of fields, such as genetics, ecology and evolution. This work adds new knowledge regarding composition and diversity of the Drosophila community in xerophytic areas which form continental islands in the Neotropical region. This approach is important for further studies in any field considering Drosophila as a model.

Acknowledgments - FAPESP provided a PhD fellowship for Rogério P. Mateus (Proc. number 97/13822-4 and RTB 1998/17903). This work was also supported by CNPq, CAPES, FINEP, FAEPA and USP. We would like to thank Paulo Ricardo Epifânio for technical support, Prof. Luciana Paes de Barros Machado and Prof. Mauricio Osvaldo Moura for useful suggestions. 


\section{REFERENCES}

AB'SABER, A. N., 1977, Espaços ocupados pela expansão dos climas secos da América do Sul, por ocasião dos períodos glaciais quaternários. Paleoclimas, 3: 1-19.

AMORIN, D. S. \& PIRES, M. R. S., 1996, Neotropical biogeography and method for maximun biodiversity estimation. In: C. E. M. Bicudo \& N. A. Menezes (eds.), Biodiversity in Brazil, a first approach, CNPq, São Paulo.

BÄCHLI, G., 1998, Family Drosophilidae. In: L. Papp \& B. Darvas (eds.), Contributions to a Manual of Palearctic Diptera. III. Higher Brachycera, Science Herald, Budapest.

BELO, M. \& OLIVEIRA-FILHO, J. J., 1978, Espécies domésticas de Drosophila. V. Influências de fatores ambientais no número de indivíduos capturados. Rev. Bras. Biol., 36: 903-909.

BIGARELLA, J. J., ANDRADE-LIMA, D. \& RIEHS, P. J., 1975, Considerações a respeito das mudanças paleoclimáticas na distribuição de algumas espécies vegetais e animais no Brasil. An. Acad. Brasil. Ciênc., 41: 411-464.

BIZZO, N. M. V. \& SENE, F. M., 1982, Studies on the natural populations of Drosophila from Peruíbe (SP), Brazil (Diptera, Drosophilidae). Rev. Bras. Biol., 42: 539-544.

BURla, H., da CUNHA, A. B., CAVALCANTI, A. G. L., PAVAN, C. \& DOBZHANSKY, T., 1950, Population density and dispersal rates in brazilian Drosophila willistoni. Ecology, 31: 393-404.

CASTLE, W. E., 1906, Inbreeding, cross-breeding and sterility in Drosophila. Science, 23: 153.

DAJOZ, R., 1983, Ecologia Geral. 471p. Editora Vozes, Petrópolis.

DOBZHANSKY, T. \& PAVAN, C., 1943, Studies on Brazilian species of Drosophila. Bolm. Fac. Filos. Ciênc. S. Paulo, 36 (Biol. Geral, 4): 1-72.

DOBZHANSKY, T. \& PAVAN, C., 1950, Local and seasonal variations in relative frequencies of species of Drosophila in Brazil. J. Anim. Ecol., 19: 1-14.

DUDA, O., 1924a, Beitrag zur Systematik der Drosophiliden unter besonderer Berücksichtigung der paläarktischen u. Orientalischen Arten (Diptera). Arch. Naturgesch., 90: 172234.

DUDA, O., 1924b, Revision der europaïschen Arten der Gattung Drosophila Fallén (Diptera). Ent. Medd., 14: 246-313.

DUDA, O., 1925, Die Costaricanischen Drosophiliden des ungarischen National-Museums zu Budapest. Annls hist.nat. Mus. natn. hung., 22: 149-229.

DUVERnELL, D. D. \& EANES, W. F., 2000, Contrasting molecular population genetics of four hexokinases in Drosophila melanogaster, D. simulans and D. yakuba. Genetics, 156: 1191-1201.

GRIMALDI, D. A., 1990, A phylogenetic revised classification of genera in the Drosophilidae (Diptera). Bull. Am. Mus. nat. Hist., 197: 1-139.

KLACZKO, L. B., POWELL, J. R. \& TAYLOR, C. E., 1983, Drosophila baits and yeasts: species attracted. Oecologia, 59: 411-413.
KRATZ, F. L., PINTO, L. G., BRANDÃO, D. \& FARIA, L. G., 1982, Altura de vôo e o padrão de distribuição espacial em Drosophila. Ciênc. Cult., 34: 203-209.

MEDEIROS, H. F., 2000, Assembléias de Espécies de Drosophila (Diptera; Drosophilidae) e Efeitos de Cursos d'Água sobre suas Distribuições em duas Matas de São Paulo, 98p. Dissertação (Mestrado) - Instituto de Biologia IB/UNICAMP, Campinas.

MEDEIROS, H. F. \& KLACZKO, L. B., 2004, How many species of Drosophila (Diptera, Drosophilidae) remain to be described in the forests of São Paulo, Brazil? Species lists of three forest remnats. Biota Neotropica, 4: 1-12.

MILLER, M. P., 1997, Tools for population genetic analyses - TFPGA - 1.3: A Windows program for the analysis of allozyme and molecular population genetic data. Computer software distributed by author.

MORAES, E. M., MATEUS, R. P. \& SENE, F. M., 2000, Ocurrence and fluctuation in population size of a recently introduced Drosophilidae species in Brazil. In: ABSTRACTS OF XXI INTERNATIONAL CONGRESS OF ENTOMOLOGY, BOOK I. Proceedings..., 271p.

MOURÃO, C. A., GALlO, A. J. \& BICUDO, H. E. M. C., 1965, Sobre a Sistemática de Drosophila no Brasil, com a descrição de D. mendeli sp.n. e "Relação de Espécies Brasileiras do Gênero Drosophila". Ciênc. Cult., 17: $577-$ 585.

PAVAN, C., 1950, Espécies Brasileiras de Drosophila. II. Bolm. Fac. Filos. Ciênc. S. Paulo, 111 (Biol. Geral, 8): 1-37.

PAVAN, C., 1959, Relações entre populações naturais de Drosophila e o meio ambiente. Bolm. Fac. Filos. Ciênc. S. Paulo, 221 (Biol. Geral, 11): 1-81.

PAVAN, C. \& da CUNHA, A. B., 1947, Espécies Brasileiras de Drosophila. Bolm. Fac. Filos. Ciênc. S. Paulo, 86 (Biol. Geral, 7): 3-47.

PAVAN, C., DOBZHANSKY, T. \& BURLA, H., 1950, Diurnal behavior of some neotropical species of Drosophila. Ecology, 31: 36-43.

PERONDINI, A. L. P., SENE, F. M. \& MORI, L., 1979, The pattern and polymorphism of some Drosophila simulans esterases in Brazil. Egypt. J. Genet. Cytol., 8: 263-268.

SENE, F. M., VAL, F. C., VILELA, C. R. \& PEREIRA, M. A. Q. R., 1980, Preliminary data on the geographical distribution of Drosophila species within morphoclimatic domains of Brazil. Pap. Avul. Dep. Zool. Sec. Agric., 33: 315-326.

SENE, F. M., PEREIRA, M. A. Q. R., VILELA, C. R. \& BIZZO, N. M. V., 1981, Influence of different ways to set baits for collection of Drosophila flies in three natural environments. D. I. S., 56: 118-121..

STALKER, H. D., 1976, Chromosome studies in wild population of D. melanogaster. Genetics, 82: 323-347.

STURTEVANT, A. H., 1921, The North American species of Drosophila. Carnegie Inst. Wash. Publ., 301: 1-150.

STURTEVANT, A. H., 1939, On the subdivision of the genus Drosophila. Proc. Natl. Acad. Sci. USA, 3: 137-141.

STURTEVANT, A. H., 1942, The classification of the genus Drosophila, with descriptions of nine new species. Univ. Texas Publ., 4213: 6-51. 
TIDON-SKLORZ, R. \& SENE, F. M., 1992, Vertical and temporal distribution of Drosophila (Diptera, Drosophilidae) species in a wooded area in the state of São Paulo, Brazil. Rev. Bras. Biol., 52: 311-317.

TIDON-SKLORZ, R. \& SENE, F. M., 1995, Fauna of Drosophila (Diptera, Drosophilidae) in the northern area of the "Cadeia do Espinhaço", States of Minas Gerais and Bahia, Brazil: Biogeographical and ecological aspects. Iheringia, Sér. Zool., 78: 85-94.

TIDON-SKLORZ, R. \& SENE, F.M., 1999, Drosophila. In: C. R. F. Brandão \& E. M. Cancello (eds), Invertebrados Terrestres. Vol.V. Biodiversidade do Estado de São Paulo. Síntese do Conhecimento ao Final do Século XX, FAPESP, São Paulo.

TIDON-SKLORZ, R. \& SENE, F. M., 2001, Two new species of the Drosophila serido sibling set (Diptera, Drosophilidae). Iheringia, Sér. Zool., 90: 141-146.

VAL, F. C. \& KANESHIRO, K. Y., 1988, Drosophilidae (Diptera) from the Estação Biológica de Boracéia, on the coastal range of the State of São Paulo, Brazil: Geographical distribution. In: P. E. Vanzolini \& W. R. Heyer (eds.), Proceedings of a Workshop on Neotropical Distribution Patterns, Academia Brasileira de Ciências, Rio de Janeiro.

VAL, F. C. \& SENE, F. M., 1980, A newly introduced Drosophila species in Brazil. Pap. Avul. Dep. Zool. Sec. Agric., 33: 293-298.
VAL, F. C., VILELA, C. R. \& MARQUES, M. D., 1981, Drosophilidae of the Neotropical Region. In: M. Ashburner, H. L. Carson \& J. N. Thompson (eds.), The genetics and biology of Drosophila, Academic Press, London.

VANZOLINI, P. E., 1981, A quasi-historical approach to the natural history of the differentiation of reptiles in tropical geographic isolates. Pap. Avul. Dep. Zool. Sec. Agric., 34: $189-204$

VERMEIJ, G. J., 1996, An agenda for invasion biology. Biol. Conserv., 78: 3-9.

VILELA, C. R., 1983, A revision of the Drosophila repleta species group (Diptera, Drosophilidae). Rev. Bras. Entomol., 27: 114.

VILELA, C. R., 1999, Is Zaprionus indianus Gupta, 1970, (Diptera, Drosophilidae) currently colonizing the Neotropical region? D. I. S., 82: 37-39.

VILELA, C. R., PEREIRA, M. A. Q. R. \& SENE, F. M., 1983, Preliminary data on the geographical distribution of Drosophila species within morphoclimatic domains of Brazil.II. The repleta group. Ciênc. Cult., 35: 66-70.

ZAR, J. H., 1999, Multiple Comparisons. In: Biostatistical Analysis. $4^{\text {th }}$ ed., Prentice Hall Inc., New Jersey. 